\title{
QUALITY OF HEALTH SERVICES FOR PATIENTS WITH DIABETES MELLITUS ACCORDING TO MINIMUM SERVICE STANDARD
}

\author{
Ernest Eugene Lie Gultom'), Besral'2) \\ ${ }^{1)}$ Master Program of Quality Health Care, Faculty of Public Health, Universitas Indonesia \\ ${ }^{2)}$ Department of Biostatistics, Faculty of Public Health, Universitas Indonesia
}

\begin{abstract}
Background: Diabetes is a growing health problem worldwide. It is a chronic illness that requires continuing medical care and management. Diabetes care management involves multiple aspects that go beyond drug therapy to providing high quality care. However, many patients with diabetes mellitus are not receiving good quality of diabetes care according to minimum service standard. This study aimed to investigate the quality of health services for patients with diabetes mellitus according to minimum service standard.

Subjects and Method: This was a qualitative study conducted at the Community Health Center in sub-district X, South Jakarta, from 26 to 31 July 2019. A total of 14 informants were selected for this study including chairman of individual health effort unit at the Community Health Center, person in charge of non-communicable disease program, and 12 staff of non-communicable disease program. The data was collected by in-depth interview, focus group discussion, and document review. The data were analyzed descriptively.

Results: The target output of health care for diabetic patients had not been achieved. According to standard set by the Ministry of Health, input and process were insufficient to achieve output. Factors affecting poor health service were high workload of staff, lack of training, lack of crosssectorial support, and poor collection of diabetes screening data.

Conclusion: Targeted quality of health care for diabetic patients has not met minimum service standard.
\end{abstract}

Keywords: quality, healthcare, minimum service standard, diabetes mellitus

\section{Correspondence:}

Ernest Eugene Lie Gultom. Masters Program of Quality Health Care, Faculty of Public Health, Universitas Indonesia, Depok, West Java. Email: ernest.s2mutu@gmail.com. Mobile: 081210663553 .

\section{BACKGROUND}

In June 2018, WHO stated that there were 15 million people died per year between the ages of 30 to 69 years due to non-communicable diseases; more than $85 \%$ of these premature deaths occurred in low and middle income countries. Early mortality due to diabetes is ranked fourth, as many as 1.6 million people each year (World Health Organization, 2018).

The process of implementing the Minimum Service Standards (MSS) can be carried out adequately by ensuring the pro- vision of sufficient resources. It is expected that the MSS concept which is a provision of basic service quality for every citizen can reach the required target of $100 \%$ annually. This study aimed to analyze the fulfilment of health services in patients with diabetes mellitus according to the MSS at the Community Health Center in $\mathrm{X}$ sub-district area.

Based on the Third SDG's relating to health which was officially established at the United Nations General Assembly on 25 September 2015, one of the efforts to improve health and wellbeing was by reducing 
one-third of premature deaths due to noncommunicable diseases through prevention and treatment and improving mental health and wellbeing in 2030. It is also a commitment of the Government of Indonesia to be implemented as well as possible (Subandi 2017).

In Indonesia, the result of the Basic Health Research in 2018 showed that the prevalence of Non-Communicable Diseases increased compared to the Basic Health Research in 2013. They were cancer, stroke, chronic kidney disease, diabetes mellitus, and hypertension. Therefore, the prevention and early detection become very important to reduce the burden on the country in the future. The prevalence of diabetes mellitus increased from $6.9 \%$ to $8.5 \%$ (Basic Health Research, 2018).

The Government of Indonesia through Law number 23 of 2014 regarding Local Government makes health a mandatory effort by the regional government because health is a basic need for every Indonesian citizen. It is supported in the Regulation of the Minister of Health No. 43 of 2016 concerning Minimum Service Standards (MSS) in the Health Sector, Government Regulation Number 2 of 2018 and Regulation of the Minister of Health No. 4 of 2019.

They explain that the MSS in the health sector is the responsibility of local governments. The MSS at the regency level consists of twelve types of basic health services. It is the obligation of the governments of regency/city to be implemented for all citizens. The MSS number nine: each patient with Diabetes Mellitus gets health services according to the standard (Minister of Health Regulation, 2019).

According to the regulation of Community health center management at the Regulation of Minister of Health No. 44 in
2016, Community health center is responsible to carried out the duties of the regency/city health office, including activities in the MSS for Regency/City Health Sector (Minister of Health Regulation, 2016).

The process of implementing the Minimum Service Standards (MSS) can be carried out adequately by ensuring the provision of sufficient resources. It is expected that the MSS concept which is a provision of basic service quality for every citizen can reach the required target of $100 \%$ annually.

Community health center is a healthcare facility that organizes Community Health Efforts and Individual Health Efforts in its working area. Community Health Efforts carry out activities aimed at maintaining and improving health as well as preventing and overcoming the health problems that attack families, groups and communities. Individual Health Efforts aim to improve, prevent, cure disease, reduce suffering due to illness, and restore individual health (Regulation of Minister of Health, 2014).

In the service activities based on the Management in the Community health center, supervision and control need to be carried out, thus optimally reaching the output targets of each activity. The Performance Assessment of the Community health center is an objective and systematic process in collecting, analyzing, and using information in order to determine how effectively and efficiently the services of the Community health services are provided, as well as targets achieved as an Performance Assessment of work/achievements of the Community health center. The Performance Assessment of the Community health center is carried out by the Community health center. The results of the assessment will be veryfied by the regency/city health office. The coverage of healthcare service achieved 
were essential Community Health Efforts in the form of health promotion services, environmental health care, maternal, child and family planning health services, nutrition services, and disease prevention and control services carried out by health screening.

This study aimed to analyze the fulfilment of health services in patients with diabetes mellitus according to the MSS at the Community Health Center in X subdistrict area in terms of input, process, and output.

\section{SUBJECTS AND METHOD \\ 1. Study Design}

This was a qualitative study which aimed to get a general understanding of the social reality of the participant perspective (Martha et al., 2016) with the Rapid Assessment Procedure (RAP) design or rapid study obtained from understanding the situation of the informant's perspective (Sutopo, 2002). This study used in-depth interview, FGD, and observation to collect the data. The informants were the Head of the Individual Health Efforts Implementation Unit, the person in charge of the Non-Communicable Diseases program, and 12 implementers of the Non-Communicable Diseases program.

This study used the theory of Donabedian, namely the structure aspects (HR, funds, facilities, policies, and SOP), the process aspects (planning, organizing, implementing, monitoring and evaluating), and the output (Donabedian 1980). In this study conducted at the District X Health Center. This study was conducted in July 2019.

The data were analyzed by using an Interactive Model Analysis. It was an analysis process by using four components of the process started from collecting the data to obtain the information, reducing data by summarizing the information obtained, presenting data in the form of narrative text, and concluding or verifying (Martha et al., 2016). This analysis was possible to do while the researcher was still temporarily collecting the data and after collecting the data. This occurred continuously until no more new information was obtained.

\section{RESULTS}

1. Input

Based on the result of the interview, there were several problems in fulfilling the HR. The implementation of the activities at the sub-district community health center was still helped by the personnel of Knock Door Serve with Heart, but there was a lack of human resources at the village level. It occurred because one staff of the Community health center was responsible for several programs. Therefore, there were difficulties in the healthcare service activities and collecting the data according to the MSS in patients with diabetes mellitus.

The funding, material, and guideline in supporting healthcare services program in patients with diabetes mellitus were still be fulfilled well.

\section{Process}

Based on the result of the interview, the planning process was conducted by preparing an Action Plan and a Plan of Action conducted in the previous year. Planning for disposable medical supplies and medicines was conducted based on the usage data. Program planning was conducted by collaborating with BPJS Health in the Chronic Disease Management Program. This program included the implementation of a promotion program for patients with diabetes mellitus.

The arrangement has been going well, because the implementer of the program was in line with the required competencies. The implementation of the services was still 
having problems. The Integrated guidance post visit for screening and controlling was not optimal due to public awareness. As a result, the Community health center conducted screening at schools in the Community health service area.

The monitoring was carried out monthly with the activities such as exposure to target achievement, the socialization of training result and the socialization of new regulations. The evaluation was conducted quarterly, even though the achievement data was monitored every month.

\section{Output}

The blood sugar measurement that was taken at least once a month in the healthcare facilities and the education regarding lifestyle changes and/ or nutrition. Based on the result of the interview, the specified target has not been reached. It occurred because the screening of new cases of patients with diabetes mellitus in the field was not optimal because the recording system has not integrated yet.

\section{DISCUSSION}

The result of the interview showed that the input was the HR. In quantity, the HR was sufficient in term of competence. However, there were limited numbers of workers. It occurred because one staff was responsible on several programs. Therefore, the results were not optimal.

This is in line with a previous study that high workloads could cause in low achievement of the MSS indicator. Some policies to strengthen the human resources in the Community health center to ensure the adequacy of the types and number of the human resources in the Community health center were in line with the main tasks and functions. A region could complete HR through innovative ways.
There were three things that generally inhibited the performance of the parties in the Community health center, namely lack of staff or non-standard personnel, the availability of drugs/vaccines/medical devices and disposable medical supplies, and the availability of budget/funds given on time. All three problems were experienced by almost all Community health centers, especially the Community health centers in remote/ underdeveloped areas.

In order to overcome these problems, the affirmative policies by the Central Government need to be implemented. It includes the procurement and placement of the personnel of the Community health center, the procurement of drugs/medical devices and disposable medical supplies, and the procurement of the operational costs for the Community health center (Indonesian Ministry of National Development Planning, 2018).

The result of the interview at the stage of the process was divided into planning, organizing, implementing, monitoring and evaluating. At the planning stage, it has been implemented well. The one thing that has not been optimal was the determination of the number of targets that were not possible to reached in a short time. The ninth MSS target was 100\%.

\begin{tabular}{l}
\hline REFERENCES \\
\hline Donabedian, A (1980). The Definition of \\
Quality and Approaches to Its Asses- \\
sment. Vol 1. Explorations in Quality \\
Assessment and Monitoring., The \\
University of Michigan, Michigan. \\
Martha, Evi, Kresno S (2016), Metodologi \\
Penelitian Kualitatif Untuk Bidang \\
Kesehatan (Qualitative Research Met- \\
dhodology for the Health Sector), \\
Jakarta: Rajawali Pers.
\end{tabular}


Ministry of Health (2016a). Peraturan Menteri Kesehatan Tentang Manajemen Puskesmas.

Ministry of Health (2016b). Permenkes No. 43 Tahun 2016 tentang Standar Pelayanan Minimal Bidang Kesehatan. 2016.

Ministry of Health (2018). Hasil utama Riskesdas (2018). Jakarta: Badan Penelitian dan Pengembangan Kesehatan, Kementrian Kesehatan Republik Inonesia.
Subandi S (2017). Pengarusutamaan Kesehatan Dalam Sustainable Development Goals (SDGs) Subandi Sardjoko, 1-28. Retrieved from http://www.konas-promkes.com/2017/uploads/article/article_13.pdf

World Health Organization (2018). Diabetes. Retrieved from http://www.who.int/topics/diabetes_mellitus/en/ 